\title{
Long Term Effect of Manure and Fertilizers on Chemical Fractions of Fe and Mn in Surface Soils under Rice-Wheat System
}

\author{
M.K. Dhaliwal ${ }^{1}$, S.S. Dhaliwal ${ }^{2} *$ and A.K. Shukla ${ }^{3}$ \\ ${ }^{1}$ Department of Soil and Water Conservation, Punjab, India \\ ${ }^{2}$ Department of Soil Science, Punjab Agricultural University, Ludhiana, India \\ ${ }^{3}$ Project Coordinator, Indian Institute of Soil Science, Bhopal, Madhya Pradesh, India \\ *Corresponding author
}

Keywords

WSEX, SpAd, $\mathrm{MnOX}, \mathrm{AFeOX}$, $\mathrm{CFeOX}$, OMbound, RES, Fe and Mn, Biogas slurry manure, Chemical fertilizers, Ricewheat system

Article Info

Accepted:

22 January 2019

Available Online:

10 February 2019

\section{A B S T R A C T}

The present research study has been conducted with prime objective to investigate the effect of manure and fertilizers on chemical fractions of $\mathrm{Fe}$ and $\mathrm{Mn}$ under rice-wheat system. Laboratory analysis was made on the soil samples collected (October 2013) from an on-going long-term field experiment (in progress since Kharif2009-10) at Department of Soil Science, PAU, Ludhiana. The organic manure through bio gas slurry (BGS) @ $6 \mathrm{t}$ $\mathrm{ha}^{-1}$ was incorporated along with nitrogen ( $\mathrm{N} @ 80$ and $120 \mathrm{~kg} \mathrm{ha}^{-1}$ ), phosphorus (P@30 $\left.\mathrm{kg} \mathrm{ha}^{-1}\right)$ and potassium fertilizer $\left(\mathrm{K} @ 30 \mathrm{~kg} \mathrm{ha}^{-1}\right)$ to the rice crop. On the other hand in the wheat crop, nitrogen ( $\mathrm{N} @ 120 \mathrm{~kg} \mathrm{ha}^{-1}$ ), phosphorus ( $\mathrm{P} @ 0,30$ and $60 \mathrm{~kg} \mathrm{ha}{ }^{-1}$ ) and potassium fertilizer ( $\mathrm{K} @ 30 \mathrm{~kg} \mathrm{ha}^{-1}$ ) were applied without addition of organic manure. It was observed that the concentration of micronutrients was found higher in the fractions where organic manure was applied along with chemical fertilizers. It was found that the residual micronutrient fraction is the dominant portion of total $\mathrm{Fe}$ and $\mathrm{Mn}$ fraction. The WSEX fraction contributed limited in amount as compared to the other fractions. Among chemical fractions viz. WSEX, SpAd, MnOX, AFeOX, CFeOX, OM-bound associated with $\mathrm{Zn}, \mathrm{Cu}, \mathrm{Fe}$ and $\mathrm{Mn}$ showed their edge with combined application of manure and chemical fertilizers. However, WSEX, SpAd, CFeOX and OM-bound fractions contributed towards uptake of micronutrients by wheat and rice grains.

\section{Introduction}

Rice-wheat cropping system is most vital cropping system of Indian subcontinent. Rice (Oryza sativa L.) and wheat (Triticum aestivum L.) are the two most important energy giving food globally (Singh et al., 2011; Meena et al., 2013). Rice and wheat grown sequentially in an annual rotation
(Singh and Singh, 2009) constitute a ricewheat cropping system (RWCS) and in a system occupy nearly 13.5 million hectares area in the Indo-Gangetic Plains (IGP) of South Asia. Integrated nutrient management practices for rice-wheat cropping system are of supreme importance for sustainable crop production in country (Singh and Kumar, 2009).The study of various fractions of $\mathrm{Fe}$ 
and Mn present in soil and conditions under which they become available to plants is prerequisite in assessing their availability to plants. It is important to know the relationship between chemical fractions of micronutrients in the soil and their uptake by the crop. Under continuous cropping system, micronutrients are generally considered to be present in association with soil solution, organic and inorganic solid phases and this association is often referred to as speciation (Behera et al., 2009), thus, forming their various chemical fractions such as water soluble plus exchangeable, specifically absorbed and those associated with free calcium carbonate, oxide surfaces, soil organic matter and minerals.

The alternate flooding (reduced stage) in rice and upland (oxidized stage) conditions in wheat affects transformation of $\mathrm{Zn}$ and $\mathrm{Cu}$ from one chemical form to another (Manchanda et al., 2003). Dhaliwal (2008) reported that green manure and soil applied $\mathrm{Mn}$ to rice-wheat system increased the DTPA-extractable, water soluble plus exchangeable and Mn specifically adsorbed on the inorganic sites whereas, Mn held on organic sites and oxide bound surfaces decreased. Duhan and Singh (2002) reported that the use of organic manures increased uptake of micronutrients which may be attributed to increase in DTPA-extractable Zn and Fe in soil and to increased yield by these organic materials. Sekhon et al., (2006) reported that application of organic manures resulted in increase and redistribution of $\mathrm{Zn}$ from non-available forms to readily available (water-soluble plus exchangeable) and potentially available forms in soil.

Hellal (2007) reported that addition of composted mixtures increased $\mathrm{MnOX}-\mathrm{Zn}$ in soil as a result $\mathrm{Fe}$ availability is increased in calcareous soil by high acidulation effect of compost. Herencia et al., (2008) showed that percentage of $\mathrm{Zn}$ in the specific fractions with respect to total content are $\mathrm{Zn}$ and addition of OM caused $\mathrm{Zn}$ to move from less soluble forms to more plant available fraction which was always favoured by organic amendment. Sekhon et al., (2006) reported that addition of $\mathrm{GM}$ to rice increased $\mathrm{AFeOX}$ form of $\mathrm{Zn}$ under rice-wheat rotation. Hellal (2007) reported that addition of composted mixtures increased amorphous Fe oxide but occluded fractions did not differ significantly due to application of composted mixtures. Consequently, the present research study was conducted with a prime objective to investigate the effect of manure and fertilizers on transformations (distribution) of micronutrients (Fe and $\mathrm{Mn}$ ) in soil.

\section{Materials and Methods}

In order to achieve the objectives mentioned earlier, laboratory studies were made on the soil samples collected from an on-going longterm experiment on role of manure and fertilizers in rice-wheat cropping system (in progress since Kharif 2009-10) at Department of Soil Science, Punjab Agricultural University, Ludhiana. The soil of experiment field was classified as Typic Ustochrept. The experiment was laid out in a split plot design with four main and three sub treatments. The organic manure through bio gas slurry (BGS) @ $6 \mathrm{t} \mathrm{ha}^{-1}$ was incorporated along with nitrogen fertilizer ( $\mathrm{N} @ 80$ and $120 \mathrm{~kg} \mathrm{ha}^{-1}$ ), phosphorus fertilizer ( $\mathrm{P} @ 30 \mathrm{~kg} \mathrm{ha}^{-1}$ ) and potassium fertilizer ( $\mathrm{K} @ 30 \mathrm{~kg} \mathrm{ha}^{-1}$ ) were applied to the rice crop. Whereas in wheat crop, nitrogen fertilizer ( $\mathrm{N} @ 120 \mathrm{~kg} \mathrm{ha}^{-1}$ ), different levels of phosphorus fertilizer ( $\mathrm{P} @$ 30 and $\left.60 \mathrm{~kg} \mathrm{ha}^{-1}\right)$ and potassium fertilizer ( $\mathrm{K}$ @ $30 \mathrm{~kg} \mathrm{ha}^{-1}$ ) were applied (Table 1).

\section{Laboratory analysis}

The soil samples were used to fractionate into following chemical forms as per sequential extraction procedure described below: 
Water soluble plus exchangeable fraction (WSEX)

Five grams of soil was shaken with $20 \mathrm{ml}$ of $0.005 \mathrm{M} \mathrm{Pb}\left(\mathrm{NO}_{3}\right)_{2}$ in $100 \mathrm{ml}$ centrifuge tubes for fifteen minutes at $25^{\circ} \mathrm{C}$ in Orbital shaker and mixture was centrifuged for ten minutes at $6000 \mathrm{rpm}$ the supernatant filtered, separated and stored for analysis (Manchanda et al., 2006).

The Reagent $0.005 \mathrm{M} \mathrm{Pb}\left(\mathrm{NO}_{3}\right)_{2}$ is prepared by dissolving $1.65 \mathrm{gm}$ of lead nitrate in one litre adjusting the $\mathrm{pH}$ of solution to 6.8 by $0.5 \mathrm{M}$ ammonium acetate $\left(\mathrm{NH}_{4} \mathrm{OAC}\right)$ which is prepared by dissolving $38.5 \mathrm{gm}$ of ammonium acetate in 1 litre.

\section{Specifically adsorbed (SpAd) fraction}

The soil residue from water soluble plus exchangeable fraction was shaken with $20 \mathrm{ml}$ of $0.05 \mathrm{M} \mathrm{Pb}\left(\mathrm{NO}_{3}\right)_{2}$ for 2 hours at $25^{\circ} \mathrm{C}$ in orbital shaker and; the sample was, thereafter, centrifuged ten minutes at $6000 \mathrm{rpm}$ and the supernatant filtered (Iwaski et al., 1993).

The sequential extraction continued in the remaining of the soil sample The Reagent $0.05 \mathrm{M} \mathrm{Pb}\left(\mathrm{NO}_{3}\right)_{2}$ is prepared by dissolving $16.56 \mathrm{gm}$ lead nitrate in one litre adjusting the $\mathrm{pH}$ of solution to 6.0 by $0.5 \mathrm{M}$ ammonium acetate $\left(\mathrm{NH}_{4} \mathrm{OAC}\right)$

\section{Mn-Oxide bound fraction (MnOX)}

To the remaining soil sample $20.0 \mathrm{ml}$ of $\mathrm{NH}_{2} \mathrm{OH} . \mathrm{HCl}$ (hydroxylamine hydrochloride) $0.1 \mathrm{~mol} \mathrm{l}^{-1}$ at $\mathrm{pH} 2.0$ were added and the mixture was shaken for $30 \mathrm{~min}$, centrifuged and filtered; the separated supernatant was stored for analysis (Chao, 1972). The Reagent $0.1 \mathrm{M} \mathrm{NH} \mathrm{NH}_{2} \mathrm{OH} . \mathrm{HCl}$ in $0.01 \mathrm{M} \mathrm{HNO}_{3}$ is prepared by dissolving $6.95 \mathrm{gm}$ of $\mathrm{NH}_{2} \mathrm{OH} . \mathrm{HCl}$ and 0.625 Nitric acid $\left(\mathrm{HNO}_{3}\right)$ in water and make the volume to one litre.

\section{Amorphous Fe-Oxides bound (AFeOX) fraction}

To the Mn-Oxide Bound Fraction free soil sample $20.0 \mathrm{ml}$ of $\mathrm{NH}_{2} \mathrm{OH} . \mathrm{HCl}$ (hydroxylamine hydrochloride) $0.1 \mathrm{~mol} \mathrm{l}^{-1}$ plus $\mathrm{HCl} 0.25 \mathrm{~mol} \mathrm{l}^{-1}$, at $\mathrm{pH} 1.3$ were added, and the mixture was shaken for $30 \mathrm{~min}$ at $25^{\circ} \mathrm{C}$ in orbital shaker, centrifuged and filtered; the separated supernatant was stored for analysis (Maskina et al., 1998). The reagent $0.25 \mathrm{M} \mathrm{NH}_{2} \mathrm{OH} . \mathrm{HCl}+0.25 \mathrm{M} \mathrm{HCl}$ is prepared by dissolving $17.37 \mathrm{gm}$ of $\mathrm{NH}_{2} \mathrm{OH} . \mathrm{HCl}$ in water and pour $21 \mathrm{ml}$ of Hydrochloric acid $(\mathrm{HCl})$ in it and make the volume of solution to one litre.

\section{Crystalline Fe-Oxides bound (CFeOX) fraction}

To the $\mathrm{AFeOx}$ free soil sample $20.0 \mathrm{ml}$ of $0.25 \mathrm{M} \mathrm{NH}_{2} \mathrm{OH} . \mathrm{HCl}+0.25 \mathrm{M} \mathrm{HCl}+$ ascorbic acid $0.01 \mathrm{~mol} \mathrm{l}^{-1}$, at $\mathrm{pH} 1.21$ were added, the mixture was heated with boiling water $\left(100^{\circ} \mathrm{C}\right)$ in a beaker placed on hot plate for 30 minutes, shaking from time to time; there after centrifuged and filtered; the separated supernatant was stored for analysis (Manchanda et al., 2006). The sequential extraction continued in the remaining of the soil sample The Reagent $0.25 \mathrm{M} \mathrm{NH}_{2} \mathrm{OH} . \mathrm{HCl}$ $+0.25 \mathrm{M} \mathrm{HCl}+0.1 \mathrm{M}$ ascorbic acid is prepared by dissolving $17.37 \mathrm{gm}$ of $\mathrm{NH}_{2} \mathrm{OH} . \mathrm{HCl}$ in water, pour $21 \mathrm{ml}$ of hydrochloric acid $(\mathrm{HCl})$ and $17.61 \mathrm{gm}$ of ascorbic acid in it and make the volume of solution to one litre.

\section{Organically bound $(\mathrm{OM})$ fraction}

To the $\mathrm{CFeOX}$ free soil sample was shaken with $20 \mathrm{ml}$ of $1 \% \mathrm{Na}_{4} \mathrm{P}_{2} \mathrm{O}_{7}$ for one hour at $25^{\circ} \mathrm{C}$ in Orbital shaker and mixture was centrifuged for ten minutes at $6000 \mathrm{rpm}$ the supernatant filtered, separated and stored for analysis (Raja and Iyengar, 1986). The 
Reagent prepared by dissolving 4.46 gm of Sodium-pyrophosphate in one litre.

\section{Residual (RES) fraction}

Residual fraction (cation) $=$ Total content (cation) - sum of all fractions (cation). The amount of $\mathrm{Zn}, \mathrm{Cu}, \mathrm{Mn}$ and $\mathrm{Fe}$ in different fractions was estimated using atomic absorption spectrophotometer.

\section{Statistical analysis}

Critical difference (CD) was used to compare the treatment effects at $\mathrm{P}<0.05$. The statistical analysis was done with the help of method described (Panse and Sukhatme, 1985).

\section{Results and Discussion}

\section{Effect of manure and fertilizers on chemical fractions of $\mathrm{Fe}$}

The data for WSEX-Fe presented in Table 2 of the surface soil samples which were collected after harvesting of rice ranged from 0.11 to $0.16 \mathrm{mg} \mathrm{kg}^{-1}$ in all the treatments. Significant increase in WSEX-Fe contents was observed in the treatments where organic manure@6 t ha ${ }^{-1}$ was incorporated along with $\mathrm{N} @ 80 \mathrm{~kg} \mathrm{ha}^{-1}$ and $\mathrm{P}_{2} \mathrm{O}_{5} @ 30 \mathrm{~kg}$ ha $^{-1}$ and in the treatments where organic manure@6 $\mathrm{t} \mathrm{ha}^{-1}$ was applied along with $\mathrm{N}$ @ $80 \mathrm{~kg} \mathrm{ha}^{-1}$ without phosphatic fertilizer as compared to the treatments where only N @ $120 \mathrm{~kg} \mathrm{ha}^{-1}$ was applied without organic manure and $\mathrm{P}_{2} \mathrm{O}_{5}$ application to the rice crop and also in the treatments where only $\mathrm{N} @$ $120 \mathrm{~kg} \mathrm{ha}^{-1}$ and $\mathrm{P}_{2} \mathrm{O}_{5} @ 30 \mathrm{~kg} \mathrm{ha}^{-1}$ were applied without addition of organic manure to the rice crop. Hellal (2007) reported from his green house experiment that the addition of organic manure increased WSEX-Fe in soil, as a result of application of organic mixture. Similarly, Maskina et al., (1998) observed an increase in WSEX fraction of Fe with addition of organic manure. Long-term application of farmyard manure also increases the organic matter content in soil which also enhances $\mathrm{Zn}$ and Fe availability (Rehman et al., 2012). Earlier studies have shown that FYM and single super phosphate contain considerable amount of $\mathrm{Fe}$, which, when applied to the soil, results in higher availability of this micronutrient (Walia et al., 2010), and thus, the crop uptake of this micronutrient significantly increases (Mann et al., 2006).

The SPAD-Fe reported significantly higher magnitude in the treatments where organic manure@6 tha ${ }^{-1}$ was added in combination with $\mathrm{N} @ 80 \mathrm{~kg} \mathrm{ha}^{-1}$ and $\mathrm{P}_{2} \mathrm{O}_{5} @ 30 \mathrm{~kg} \mathrm{ha}^{-1}$ and also in the treatments where organic manure@6 t ha ${ }^{-1}$ was incorporated along with $\mathrm{N} @ 80 \mathrm{~kg} \mathrm{ha}^{-1}$ was applied without incorporation of phosphatic fertilizer in contrast to the treatments where no organic manure was incorporated and only N @ 120 $\mathrm{kg} \mathrm{ha}{ }^{-1}$ was applied without $\mathrm{P}_{2} \mathrm{O}_{5}$ application to the rice crop. The SPAD-Fe varied from 0.25 to $0.27 \mathrm{mg} \mathrm{kg}^{-1}$ in the treatments where organic manure and inorganic fertilizers were applied in combination and it was ranged from 0.20 to $0.24 \mathrm{mg} \mathrm{kg}^{-1}$ and 0.22 to $0.24 \mathrm{mg} \mathrm{kg}^{-1}$ in the treatments where no organic manure was incorporated and only inorganic fertilizers were applied. Iu et al., (1981) reported increase in amount of SPAD-Fe with addition of organic manure. These results are also in agreement with the results obtained by Chatterjee et al., (1992) who reported increase in this form with addition of organic manure.

The MnOX-Fe showed significant increase in its fractions with fertilizers and manure. It was reported higher in the treatments where organic and inorganic fertilizers were applied in combination as compared to the treatments where only chemical fertilizers were applied to the rice crop. The $\mathrm{MnOX}-\mathrm{Fe}$ ranged from 
44.77 to $48.73 \mathrm{mg} \mathrm{kg}^{-1}$ in the treatments organic manure@6 tha $\mathrm{ha}^{-1}$ was incorporated along with $\mathrm{N} @ 80 \mathrm{~kg} \mathrm{ha}^{-1}$ and $\mathrm{P}_{2} \mathrm{O}_{5} @ 30 \mathrm{~kg}$ $\mathrm{ha}^{-1}$ were applied and 41.58 to $43.25 \mathrm{mg} \mathrm{kg}^{-1}$ in the treatments where organic manure @6 $\mathrm{t} \mathrm{ha}^{-1}$ was incorporated along with $\mathrm{N} @ 80$ $\mathrm{kg} \mathrm{ha}^{-1}$ was applied without incorporation of phosphatic fertilizer. On the other hand, it varied from 36.72 to $38.35 \mathrm{mg} \mathrm{kg}^{-1}$ in the treatments where no organic manure was incorporated and only N @ $120 \mathrm{~kg} \mathrm{ha}^{-1}$ was applied without $\mathrm{P}_{2} \mathrm{O}_{5}$ application to the rice crop and 39.12 to $41.03 \mathrm{mg} \mathrm{kg}^{-1}$ in the treatments where no manure was incorporated and only chemical fertilizers were applied. Sekhon et al., (2006) reported that addition of organic manure to rice increased potentially available fraction of $\mathrm{Fe}$ under rice-wheat rotation. Hellal (2007) reported that addition of composted mixtures increased $\mathrm{MnOX}-\mathrm{Fe}$ in soil, as a result $\mathrm{Fe}$ availability is increased in calcareous soil by high acidulation effect of compost.

The AFeOX-Fe ranged from 386.8 to 390.1 $\mathrm{mg} \mathrm{kg}{ }^{-1}$ in the treatments where organic manure @ $6 \mathrm{t} \mathrm{ha}^{-1}$ was incorporated along with $\mathrm{N} @ 80 \mathrm{~kg} \mathrm{ha}^{-1}$ and $\mathrm{P}_{2} \mathrm{O}_{5} @ 30 \mathrm{~kg} \mathrm{ha}^{-1}$ were applied. Similar pattern of increase was observed in the treatments where organic manure@6 t ha ${ }^{-1}$ was incorporated along with $\mathrm{N} @ 80 \mathrm{~kg} \mathrm{ha}^{-1}$ was applied without incorporation of phosphatic fertilizer where it ranged from 383.4 to $385.9 \mathrm{mg} \mathrm{kg}^{-1}$. Hellal (2007) reported that addition of composted mixtures increased AFeOX fraction but occluded Fe did not differ significantly due to application of composted mixtures. Agbenin (2003) reported a similar increase in AFeOX$\mathrm{Fe}$ and $\mathrm{Mn}$ fractions fertilized with NPK, FYM and FYM+NPK. Singh et al., (1988) in a study on 11 soils reported that 9 and 5 per cent of total $\mathrm{Fe}$ and $\mathrm{Mn}$ was associated with $\mathrm{AFeOX}$ fraction. The $\mathrm{CFeOX}-\mathrm{Fe}$ fraction increased in soil many folds as compared to the other fractions (Table 3). In all the treatments $\mathrm{CFeOX}-\mathrm{Zn}$ varied from 564.80 to $631.30 \mathrm{mg} \mathrm{kg}^{-1}$ where the higher content was noticed in the treatments where organic manure was incorporated along with chemical fertilizers. The significant higher concentration ranged from 616.47 to 631.30 $\mathrm{mg} \mathrm{kg}$ of this fraction was noticed in the treatments where organic manure@6 $\mathrm{t} \mathrm{ha}^{-1}$ was incorporated along with $\mathrm{N} @ 80 \mathrm{~kg} \mathrm{ha}^{-1}$ and $\mathrm{P}_{2} \mathrm{O}_{5} @ 30 \mathrm{~kg} \mathrm{ha}^{-1}$ were applied. Singh et al., (1988) and Randhawa and Singh, (1997) reported that about 52 per cent of the total soil Fe was presented in RES fraction and about 41 per cent of the total $\mathrm{Fe}$ was associated with CFeOX fraction. Similarly, Nayyar and Chhibba, (2000) reported that the prevalence of alternative oxidized and reduced conditions under rice-wheat system caused a decline in the content of $\mathrm{CFeOX}$ form concomitant with an increase in the easily reducible $\mathrm{AFeOX}$ form of these micronutrients leading to their increased availability.

The significant increase was noticed in organically bound fraction (OM-Fe) in the treatments where organic manure@6 $\mathrm{t} \mathrm{ha}^{-1}$ was incorporated along with $\mathrm{N} @ 80 \mathrm{~kg} \mathrm{ha}^{-1}$ and $\mathrm{P}_{2} \mathrm{O}_{5} @ 30 \mathrm{~kg} \mathrm{ha}^{-1}$ were applied where it ranged from 24.60 to $26.28 \mathrm{mg} \mathrm{kg}^{-1}$ as compared to the treatment which were treated inorganically and where no organic manure was incorporated. However, the significant difference was also observed in OM-Fe fraction in case of wheat crop where different levels of $\mathrm{P}_{2} \mathrm{O}_{5}\left(0,30\right.$ and $\left.60 \mathrm{~kg} \mathrm{ha}^{-1}\right)$ were applied. The higher concentration of OM-Fe and $\mathrm{Mn}$ in the soil solution indicated that the micronutrients associated with the OM bound fraction may play a beneficial role in the uptake of these nutrients by the plants. Sekhon et al., (2006) reported that OM bound fraction of $\mathrm{Fe}$ and $\mathrm{Mn}$ increased with application of organic manure in rice-wheat system. It was observed that application of $\mathrm{P}$ fertilizer and organic manure with incorporation of straw resulted in significant 
increases in soil total $\mathrm{Cu}, \mathrm{Zn}, \mathrm{Fe}$ and $\mathrm{Mn}(\mathrm{Li}$ et al., 2010).

Effect of manure and fertilizers on chemical fractions of Mn

The concentration of Mn in WSEX fraction ranged from 3.77 to $4.79 \mathrm{mg} \mathrm{kg}^{-1}$ in all the treatment combinations in Table 4. Significantly increased concentration of WSEX-Mn contents was observed in the treatments where organic manure @ $6 \mathrm{t} \mathrm{ha}^{-1}$ was incorporated along with $\mathrm{N} @ 80 \mathrm{~kg} \mathrm{ha}^{-1}$ and $\mathrm{P}_{2} \mathrm{O}_{5} @ 30 \mathrm{~kg} \mathrm{ha}^{-1}$ were applied where it ranged from 4.41 to $4.79 \mathrm{mg} \mathrm{kg}^{-1}$ and it ranged from 4.17 to $4.39 \mathrm{mg} \mathrm{kg}^{-1}$ in the treatments where organic manure @ $6 \mathrm{t} \mathrm{ha}^{-1}$ was incorporated along with $\mathrm{N} @ 80 \mathrm{~kg} \mathrm{ha}^{-1}$ was applied without incorporation of phosphatic fertilizer as compared to the treatments where no organic manure was incorporated and only N @ $120 \mathrm{~kg} \mathrm{ha}^{-1}$ was applied without $\mathrm{P}_{2} \mathrm{O}_{5}$ application to the rice crop where it was ranged from 3.77 to 3.81 $\mathrm{mg} \mathrm{kg}{ }^{-1}$ and in the other treatments it varied from 3.98 to $4.27 \mathrm{mg} \mathrm{kg}^{-1}$ where no manure was incorporated and only chemical fertilizers like N@120 kg ha ${ }^{-1}$ and $\mathrm{P}_{2} \mathrm{O}_{5} @ 30 \mathrm{~kg} \mathrm{ha}^{-1}$ were applied to the rice crop. The maximum concentration of WESX-Mn was reported in organically treated plots which may be attributed to the reduction of higher valent forms of $\mathrm{Mn}\left(\mathrm{Mn}^{4+}\right)$ to its available form $\left(\mathrm{Mn}^{2+}\right)$ accompanied by increase in its solubility under submerged conditions and chelating action of the organic manures. Earlier authors have reported that balanced fertilization not only increases grain yield and maintains soil nutrient balance, but also accelerates rice nutrient uptake (Mann et al., 2006; Li et al., 2007; Xue et al., 2014).

The SPAD-Mn reported significantly higher magnitude in the treatments where organic manure was incorporated in combination with chemical fertilizers in contrast to the treatments where no organic manure was incorporated and only chemical fertilizers were applied. The SPAD-Mn varied from 2.25 to $2.89 \mathrm{mg} \mathrm{kg}^{-1}$ in all the treatments. Significant higher concentrations were reported in organically treated plots. Iu et al., (1981) reported increase in amount of SPAD$\mathrm{Mn}$ with the addition of organic manure. These results are also in agreement with the results obtained by Chatterjee et al., (1992) who reported increase in this form with addition of organic manure. Dhaliwal (2008) reported that rice-wheat cropping system increased the levels of $\mathrm{Mn}$ in WSEX and SPAD on the inorganic sites, whereas $\mathrm{Mn}$ held on organic sites and oxide bound surfaces decreased.

The MnOX-Mn showed significant increase in its fractions with fertilizers and manure. It was reported higher in the treatments where organic and inorganic fertilizers were applied in combination as compared to the treatments where only chemical fertilizers were applied to the rice crop. The MnOX-Mn ranged from 61.43 to $66.20 \mathrm{mg} \mathrm{kg}^{-1}$ in the treatments organic manure@6 t ha-1 was incorporated along with $\mathrm{N} @ 80 \mathrm{~kg} \mathrm{ha}^{-1}$ and $\mathrm{P}_{2} \mathrm{O}_{5} @ 30 \mathrm{~kg}$ ha $^{-1}$ were applied and 68.20 to $73.90 \mathrm{mg} \mathrm{kg}^{-1}$ in the treatments where organic manure @ $6 \mathrm{t}$ $\mathrm{ha}^{-1}$ was incorporated along with $\mathrm{N} @ 80 \mathrm{~kg}$ $\mathrm{ha}^{-1}$ was applied without incorporation of phosphatic fertilizer. On the other hand, it varied from 52.87 to $56.63 \mathrm{mg} \mathrm{kg}^{-1}$ in the treatments where no organic manure was incorporated and only N@120 kg ha ${ }^{-1}$ was applied without $\mathrm{P}_{2} \mathrm{O}_{5}$ application to the rice crop and 50.97 to $55.40 \mathrm{mg} \mathrm{kg}^{-1}$ in the treatments where no manure was incorporated and only chemical fertilizers were applied. Sekhon et al., (2006) reported that addition of organic manure to rice increased potentially available fraction of $\mathrm{Mn}$ under rice-wheat rotation. Hellal (2007) reported that addition of composted mixtures increased $\mathrm{MnOX}-\mathrm{Mn}$ in soil, as a result $\mathrm{Fe}$ availability is increased 
in calcareous soil by high acidulation effect of compost. Herencia et al., (2008) showed the percentage of $\mathrm{Fe}$ and $\mathrm{Mn}$ in the specific fractions with respect to the total content are $\mathrm{Mn}>\mathrm{Fe}$ and addition of organic matter caused $\mathrm{Zn}$ and $\mathrm{Fe}$ to move from less soluble forms to more plant available fraction which was always favoured by organic amendments.

The AFeOX-Mn reported significantly higher concentration in the treatments where organic manure and chemical fertilizers were applied in combination to the rice crop. Among the treatments, organically treated plots showed higher release of AFeOX-Mn in solution. The $\mathrm{AFeOX}-\mathrm{Mn}$ ranged from 22.40 to $23.67 \mathrm{mg}$ $\mathrm{kg}^{-1}$ in the treatments where organic manure @ $6 \mathrm{t} \mathrm{ha}^{-1}$ was incorporated along with $\mathrm{N} @$ $80 \mathrm{~kg} \mathrm{ha}^{-1}$ and $\mathrm{P}_{2} \mathrm{O}_{5} @ 30 \mathrm{~kg} \mathrm{ha}^{-1}$ were applied. Similar increase was observed in the treatments where organic manure @ $6 \mathrm{t} \mathrm{ha}^{-1}$ was incorporated along with $\mathrm{N} @ 80 \mathrm{~kg} \mathrm{ha}^{-1}$ was applied without incorporation of phosphatic fertilizer where it ranged from 20.03 to $21.87 \mathrm{mg} \mathrm{kg}^{-1}$. However, it varied from 15.77 to $16.53 \mathrm{mg} \mathrm{kg}^{-1}$ in the treatments where no organic manure was incorporated and only $\mathrm{N} @ 120 \mathrm{~kg} \mathrm{ha}^{-1}$ was applied without $\mathrm{P}_{2} \mathrm{O}_{5}$ application to the rice crop and 17.30 to $21.87 \mathrm{mg} \mathrm{kg}^{-1}$ in the other treatments where no manure was incorporated and only chemical fertilizers like $\mathrm{N} @ 120 \mathrm{~kg} \mathrm{ha}^{-1}$ and $\mathrm{P}_{2} \mathrm{O}_{5} @ 30 \mathrm{~kg} \mathrm{ha}^{-1}$ were applied. However, the significant difference was also observed in AFeOX-Mn fraction in the wheat crop where different levels of $\mathrm{P}_{2} \mathrm{O}_{5}\left(0,30\right.$ and $\left.60 \mathrm{~kg} \mathrm{ha}^{-1}\right)$ were applied. The interaction between rice and wheat crops was found as non significant. Sekhon et al., (2006) reported that addition of organic manure to rice increased $\mathrm{AFeOX}$ form of $\mathrm{Mn}$ under rice-wheat rotation. Agbenin (2003) reported a similar increase in AFeOX-Mn fractions fertilized with NPK, FYM and FYM+NPK. Singh et al., (1988) in a study on 11 soils reported that 9 and 5 per cent of total $\mathrm{Fe}$ and $\mathrm{Mn}$ was associated with $\mathrm{AFeOX}$ fraction. The significantly higher concentration of $\mathrm{CFeOX}-\mathrm{Mn}$ fraction was reported in the treatments where organic manure was incorporated along with chemical fertilizers (Table 5).

Table.1 Treatment details of long term experiment on rice-wheat system

\begin{tabular}{|c|c|c|c|c|}
\hline \multirow{3}{*}{ Treatments } & \multicolumn{3}{|c|}{ Rice } & \multirow{3}{*}{$\begin{array}{c}\text { Wheat } \\
\mathrm{P}_{2} \mathrm{O}_{5} \\
\left(\mathrm{~kg} \mathrm{ha}^{-1}\right)\end{array}$} \\
\hline & \multirow{2}{*}{$\begin{array}{l}\text { Manure } \\
\left(\mathrm{t} \mathrm{ha}^{-1}\right)\end{array}$} & $\mathrm{N}$ & $\mathrm{P}_{2} \mathrm{O}_{5}$ & \\
\hline & & \multicolumn{2}{|c|}{$\left(\mathrm{kg} \mathrm{ha}^{-1}\right)$} & \\
\hline $\mathrm{T}_{1}$ & 0 & 120 & 0 & 0 \\
\hline $\mathrm{T}_{2}$ & 0 & 120 & 0 & 30 \\
\hline $\mathrm{T}_{3}$ & 0 & 120 & 0 & 60 \\
\hline $\mathrm{T}_{4}$ & 6 & 80 & 30 & 0 \\
\hline $\mathrm{T}_{5}$ & 6 & 80 & 30 & 30 \\
\hline $\mathrm{T}_{6}$ & 6 & 80 & 30 & 60 \\
\hline $\mathrm{T}_{7}$ & 0 & 120 & 30 & 0 \\
\hline $\mathrm{T}_{8}$ & 0 & 120 & 30 & 30 \\
\hline $\mathrm{T}_{9}$ & 0 & 120 & 30 & 60 \\
\hline $\mathrm{T}_{10}$ & 6 & 80 & 0 & 0 \\
\hline $\mathrm{T}_{11}$ & 6 & 80 & 0 & 30 \\
\hline $\mathrm{T}_{12}$ & 6 & 80 & 0 & 60 \\
\hline
\end{tabular}


Table.2 Chemical fractions of Fe (WSEX, SpAd, MnOX and AFeOX) in surface soil (0-15cm) under rice-wheat system

\begin{tabular}{|c|c|c|c|c|}
\hline \multirow[t]{2}{*}{ Treatments of rice } & \multicolumn{3}{|c|}{ Rates of $\mathrm{P}$ applied to wheat $\left(\mathrm{kg} \mathrm{P}_{2} \mathrm{O}_{5} \mathrm{ha}^{-1}\right)$} & \multirow[t]{2}{*}{ Mean } \\
\hline & $\mathrm{P}_{0}$ & $\mathrm{P}_{30}$ & $\mathrm{P}_{60}$ & \\
\hline \multicolumn{5}{|c|}{ WSEX-Fe $\left(\mathrm{mg} \mathrm{kg}^{-1}\right)$} \\
\hline $\mathbf{M}_{0} \mathbf{N}_{120} \mathbf{P}_{0}$ & 0.11 & 0.12 & 0.12 & 0.11 \\
\hline $\mathbf{M}_{6} \mathbf{N}_{80} \mathbf{P}_{30}$ & 0.15 & 0.15 & 0.16 & 0.15 \\
\hline $\mathbf{M}_{0} \mathbf{N}_{120} \mathbf{P}_{30}$ & 0.11 & 0.11 & 0.12 & 0.11 \\
\hline $\mathbf{M}_{6} \mathbf{N}_{80} \mathbf{P}_{0}$ & 0.11 & 0.13 & 0.15 & 0.13 \\
\hline Mean & 0.12 & 0.13 & 0.14 & - \\
\hline LSD $(p<0.05)$ & \multicolumn{4}{|c|}{$\mathrm{R}=0.01, \quad \mathrm{~W}=\mathrm{NS}, \quad \mathrm{R} \times \mathrm{W}=\mathrm{NS}$} \\
\hline \multicolumn{5}{|c|}{ SpAd-Fe (mg kg-1) } \\
\hline $\mathbf{M}_{0} \mathbf{N}_{120} \mathbf{P}_{0}$ & 0.22 & 0.20 & 0.24 & 0.22 \\
\hline $\mathbf{M}_{6} \mathbf{N}_{80} \mathbf{P}_{30}$ & 0.25 & 0.25 & 0.27 & 0.26 \\
\hline $\mathbf{M}_{0} \mathbf{N}_{120} \mathbf{P}_{30}$ & 0.24 & 0.22 & 0.23 & 0.23 \\
\hline $\mathbf{M}_{6} \mathbf{N}_{80} \mathbf{P}_{0}$ & 0.26 & 0.25 & 0.27 & 0.26 \\
\hline Mean & 0.24 & 0.23 & 0.25 & - \\
\hline LSD $(p<0.05)$ & \multicolumn{4}{|c|}{$\mathrm{R}=0.02, \quad \mathrm{~W}=0.009, \quad \mathrm{RxW}=0.02$} \\
\hline \multicolumn{5}{|c|}{$\operatorname{MnOX-Fe}\left(\mathrm{mg} \mathrm{kg}^{-1}\right)$} \\
\hline $\mathbf{M}_{0} \mathbf{N}_{120} \mathbf{P}_{0}$ & 36.72 & 37.84 & 38.35 & 37.64 \\
\hline $\mathbf{M}_{6} \mathbf{N}_{80} \mathbf{P}_{30}$ & 44.77 & 45.60 & 48.73 & 46.37 \\
\hline $\mathbf{M}_{0} \mathbf{N}_{120} \mathbf{P}_{30}$ & 39.12 & 41.03 & 40.78 & 40.31 \\
\hline $\mathbf{M}_{6} \mathbf{N}_{80} \mathbf{P}_{0}$ & 42.86 & 41.58 & 43.25 & 42.56 \\
\hline Mean & 40.87 & 41.51 & 42.78 & - \\
\hline LSD $(p<0.05)$ & \multicolumn{4}{|c|}{$\mathrm{R}=1.62, \mathrm{~W}=1.15, \mathrm{RxW}=\mathrm{NS}$} \\
\hline \multicolumn{5}{|c|}{$\mathrm{AFeOX}-\mathrm{Fe}\left(\mathrm{mg} \mathrm{kg}^{-1}\right)$} \\
\hline $\mathbf{M}_{0} \mathbf{N}_{120} \mathbf{P}_{0}$ & 366.5 & 368.5 & 376.8 & 370.6 \\
\hline $\mathbf{M}_{6} \mathbf{N}_{80} \mathbf{P}_{30}$ & 386.8 & 389.9 & 390.1 & 388.9 \\
\hline $\mathbf{M}_{0} \mathbf{N}_{120} \mathbf{P}_{30}$ & 377.1 & 378.5 & 382.0 & 379.2 \\
\hline $\mathbf{M}_{6} \mathbf{N}_{80} \mathbf{P}_{0}$ & 385.9 & 383.4 & 385.1 & 384.8 \\
\hline Mean & 379.1 & 380.1 & 383.5 & - \\
\hline $\operatorname{LSD}(p<0.05)$ & \multicolumn{4}{|c|}{$\mathrm{R}=1.55, \quad \mathrm{~W}=0.85, \quad \mathrm{RxW}=1.70$} \\
\hline
\end{tabular}


Table.3 Chemical fractions of Fe (CFeOX, OM, RES and Total) in surface soil $(0-15 \mathrm{~cm})$ under rice-wheat system

\begin{tabular}{|c|c|c|c|c|}
\hline \multirow[t]{2}{*}{ Treatments of rice } & \multicolumn{3}{|c|}{ Rates of $\mathrm{P}$ applied to wheat $\left(\mathrm{kg}_{2} \mathrm{O}_{5} \mathrm{ha}^{-1}\right)$} & \multirow[t]{2}{*}{ Mean } \\
\hline & $\mathrm{P}_{0}$ & $\mathrm{P}_{30}$ & $\mathrm{P}_{60}$ & \\
\hline \multicolumn{5}{|c|}{ CFeOX-Fe $\left(\mathrm{mg} \mathrm{kg}^{-1}\right)$} \\
\hline $\mathbf{M}_{0} \mathbf{N}_{120} \mathbf{P}_{0}$ & 564.8 & 570.2 & 569.5 & 568.2 \\
\hline $\mathbf{M}_{6} \mathbf{N}_{80} \mathbf{P}_{30}$ & 616.5 & 626.7 & 631.3 & 624.8 \\
\hline $\mathbf{M}_{0} \mathbf{N}_{120} \mathbf{P}_{30}$ & 579.8 & 582.3 & 585.0 & 582.4 \\
\hline $\mathbf{M}_{6} \mathbf{N}_{80} \mathbf{P}_{0}$ & 587.8 & 598.4 & 607.4 & 597.9 \\
\hline Mean & 587.2 & 594.4 & 598.3 & - \\
\hline LSD $(p<0.05)$ & \multicolumn{4}{|c|}{$\mathrm{R}=1.80, \quad \mathrm{~W}=1.32, \quad \mathrm{RxW}=\mathrm{NS}$} \\
\hline \multicolumn{5}{|c|}{ OM-bound Fe (mg kg-1) } \\
\hline $\mathbf{M}_{0} \mathbf{N}_{120} \mathbf{P}_{0}$ & 22.62 & 22.84 & 24.68 & 23.38 \\
\hline $\mathbf{M}_{6} \mathbf{N}_{80} \mathbf{P}_{30}$ & 24.60 & 26.28 & 26.02 & 25.63 \\
\hline $\mathbf{M}_{0} \mathbf{N}_{120} \mathbf{P}_{30}$ & 23.78 & 24.58 & 24.71 & 24.36 \\
\hline$M_{6} N_{80} P_{0}$ & 24.99 & 25.09 & 24.65 & 24.91 \\
\hline Mean & 23.99 & 24.70 & 25.02 & - \\
\hline $\operatorname{LSD}(p<0.05)$ & \multicolumn{4}{|c|}{$\mathrm{R}=1.15, \quad \mathrm{~W}=0.64, \quad \mathrm{RxW}=\mathrm{NS}$} \\
\hline \multicolumn{5}{|c|}{ RES-Fe (\%) } \\
\hline $\mathbf{M}_{0} \mathbf{N}_{120} \mathbf{P}_{\mathbf{0}}$ & 1.33 & 1.30 & 1.28 & 1.30 \\
\hline $\mathbf{M}_{6} \mathbf{N}_{80} \mathbf{P}_{30}$ & 1.37 & 1.36 & 1.34 & 1.36 \\
\hline $\mathbf{M}_{0} \mathbf{N}_{120} \mathbf{P}_{30}$ & 1.29 & 1.26 & 1.25 & 1.26 \\
\hline $\mathbf{M}_{6} \mathbf{N}_{80} \mathbf{P}_{0}$ & 1.41 & 1.39 & 1.38 & 1.39 \\
\hline Mean & 1.35 & 1.33 & 1.31 & - \\
\hline LSD $(p<0.05)$ & \multicolumn{4}{|c|}{$\mathrm{R}=0.01, \quad \mathrm{~W}=0.01, \quad \mathrm{R} \times \mathrm{W}=\mathrm{NS}$} \\
\hline \multicolumn{5}{|c|}{ Total-Fe $(\%)$} \\
\hline $\mathbf{M}_{0} \mathbf{N}_{120} \mathbf{P}_{0}$ & 1.43 & 1.40 & 1.38 & 1.40 \\
\hline $\mathbf{M}_{6} \mathbf{N}_{80} \mathbf{P}_{30}$ & 1.47 & 1.47 & 1.45 & 1.46 \\
\hline $\mathbf{M}_{0} \mathbf{N}_{120} \mathbf{P}_{30}$ & 1.39 & 1.36 & 1.35 & 1.37 \\
\hline$M_{6} N_{80} P_{0}$ & 1.51 & 1.49 & 1.48 & 1.49 \\
\hline Mean & 1.45 & 1.43 & 1.42 & - \\
\hline $\operatorname{LSD}(p<0.05)$ & \multicolumn{4}{|c|}{$\mathrm{R}=0.01, \quad \mathrm{~W}=0.01, \quad \mathrm{RxW}=\mathrm{NS}$} \\
\hline
\end{tabular}


Table.4 Chemical fractions of Mn (WSEX, SpAd, MnOX and AFeOX) in surface soil (0-15cm) under rice-wheat system

\begin{tabular}{|c|c|c|c|c|}
\hline \multirow[t]{2}{*}{ Treatments of rice } & \multicolumn{3}{|c|}{ Rates of $P$ applied to wheat $\left(\mathrm{kg} \mathrm{P}_{2} \mathrm{O}_{5} \mathrm{ha}^{-1}\right)$} & \multirow[t]{2}{*}{ Mean } \\
\hline & $\mathrm{P}_{0}$ & $\mathrm{P}_{30}$ & $P_{60}$ & \\
\hline \multicolumn{5}{|c|}{ WSEX-Mn (mg kg $\left.{ }^{-1}\right)$} \\
\hline $\mathbf{M}_{0} \mathbf{N}_{120} \mathbf{P}_{0}$ & 3.99 & 3.77 & 3.81 & 3.86 \\
\hline $\mathbf{M}_{6} \mathbf{N}_{80} \mathbf{P}_{30}$ & 4.41 & 4.79 & 4.64 & 4.61 \\
\hline $\mathbf{M}_{0} \mathbf{N}_{120} \mathbf{P}_{30}$ & 4.01 & 3.98 & 4.27 & 4.08 \\
\hline $\mathbf{M}_{6} \mathbf{N}_{80} \mathbf{P}_{0}$ & 4.17 & 4.25 & 4.39 & 4.27 \\
\hline Mean & 4.14 & 4.20 & 4.28 & - \\
\hline \multirow{2}{*}{\multicolumn{5}{|c|}{$\begin{array}{l}\mathrm{R}=0.41, \quad \mathrm{~W}=\mathrm{NS}, \quad \mathrm{RxW}=\mathrm{NS} \\
-\mathrm{Mn}\left(\mathbf{m g ~ k \mathbf { ~ g } ^ { - 1 } )}\right.\end{array}$}} \\
\hline & & & & \\
\hline $\mathbf{M}_{0} \mathbf{N}_{120} \mathbf{P}_{0}$ & 2.25 & 2.36 & 2.47 & 2.36 \\
\hline $\mathbf{M}_{6} \mathbf{N}_{80} \mathbf{P}_{30}$ & 2.77 & 2.80 & 2.89 & 2.82 \\
\hline $\mathbf{M}_{0} \mathbf{N}_{120} \mathbf{P}_{30}$ & 2.55 & 2.67 & 2.76 & 2.66 \\
\hline $\mathbf{M}_{6} \mathbf{N}_{80} \mathbf{P}_{0}$ & 2.85 & 2.91 & 2.69 & 2.82 \\
\hline Mean & 2.60 & 2.69 & 2.70 & - \\
\hline LSD $(p<0.05)$ & \multicolumn{4}{|c|}{$\mathrm{R}=0.20, \quad \mathrm{~W}=\mathrm{NS}, \quad \mathrm{R} \times \mathrm{W}=\mathrm{NS}$} \\
\hline \multicolumn{5}{|c|}{ MnOX-Mn (mg kg $\left.{ }^{-1}\right)$} \\
\hline $\mathbf{M}_{0} \mathbf{N}_{120} \mathbf{P}_{0}$ & 52.87 & 54.80 & 56.63 & 54.77 \\
\hline $\mathbf{M}_{6} \mathbf{N}_{80} \mathbf{P}_{30}$ & 61.43 & 62.43 & 66.20 & 63.36 \\
\hline $\mathbf{M}_{0} \mathbf{N}_{120} \mathbf{P}_{30}$ & 50.97 & 55.40 & 54.00 & 53.46 \\
\hline $\mathbf{M}_{6} \mathbf{N}_{80} \mathbf{P}_{0}$ & 68.20 & 68.80 & 73.90 & 70.30 \\
\hline Mean & 58.37 & 60.36 & 62.68 & - \\
\hline LSD $(p<0.05)$ & \multicolumn{4}{|c|}{$\mathrm{R}=1.23, \mathrm{~W}=0.81, \mathrm{RxW}=1.62$} \\
\hline \multicolumn{5}{|c|}{ AFeOX-Mn $\left(\mathrm{mg} \mathrm{kg}^{-1}\right)$} \\
\hline $\mathbf{M}_{0} \mathbf{N}_{120} \mathbf{P}_{0}$ & 15.77 & 16.13 & 16.53 & 16.14 \\
\hline $\mathbf{M}_{6} \mathbf{N}_{80} \mathbf{P}_{30}$ & 22.40 & 22.53 & 23.67 & 22.87 \\
\hline $\mathbf{M}_{0} \mathbf{N}_{120} \mathbf{P}_{30}$ & 17.30 & 19.23 & 19.63 & 18.72 \\
\hline $\mathbf{M}_{6} \mathbf{N}_{80} \mathbf{P}_{0}$ & 20.30 & 20.03 & 21.87 & 20.73 \\
\hline Mean & 18.94 & 19.48 & 20.43 & - \\
\hline $\operatorname{LSD}(p<0.05)$ & \multicolumn{4}{|c|}{$\mathrm{R}=1.08, \quad \mathrm{~W}=1.16, \quad \mathrm{RxW}=\mathrm{NS}$} \\
\hline
\end{tabular}


Table.5 Chemical fractions of Mn (CFeOX, OM, RES and Total) in surface soil $(0-15 \mathrm{~cm})$ under rice-wheat system

\begin{tabular}{|c|c|c|c|c|}
\hline \multirow[t]{2}{*}{ Treatments of rice } & \multicolumn{3}{|c|}{ Rates of $\mathrm{P}$ applied to wheat $\left(\mathrm{kg} \mathrm{P}_{2} \mathrm{O}_{5} \mathrm{ha}^{-1}\right)$} & \multirow[t]{2}{*}{ Mean } \\
\hline & $\mathrm{P}_{0}$ & $\mathrm{P}_{30}$ & $\mathrm{P}_{60}$ & \\
\hline \multicolumn{5}{|c|}{ CFeOX-Mn $\left(\mathrm{mg} \mathrm{kg}^{-1}\right)$} \\
\hline $\mathbf{M}_{0} \mathbf{N}_{120} \mathbf{P}_{0}$ & 19.47 & 19.33 & 20.14 & 19.65 \\
\hline $\mathbf{M}_{6} \mathbf{N}_{80} \mathbf{P}_{30}$ & 20.20 & 20.27 & 20.70 & 20.39 \\
\hline $\mathbf{M}_{0} \mathbf{N}_{120} \mathbf{P}_{30}$ & 16.70 & 17.13 & 18.40 & 17.41 \\
\hline $\mathbf{M}_{6} \mathbf{N}_{80} \mathbf{P}_{0}$ & 20.50 & 20.90 & 21.67 & 21.02 \\
\hline Mean & 19.22 & 19.41 & 20.23 & - \\
\hline \multirow{2}{*}{\multicolumn{5}{|c|}{$\begin{array}{l}\mathrm{R}=1.11, \quad \mathrm{~W}=0.70, \quad \mathrm{R} \times \mathrm{W}=\mathrm{NS} \\
\mathbf{d d}-\mathrm{Mn}\left(\mathbf{m g ~ k g}^{-1}\right)\end{array}$}} \\
\hline & & & & \\
\hline $\mathbf{M}_{0} \mathbf{N}_{120} \mathbf{P}_{0}$ & 1.26 & 1.28 & 1.30 & 1.28 \\
\hline $\mathbf{M}_{6} \mathbf{N}_{80} \mathbf{P}_{30}$ & 1.44 & 1.48 & 1.55 & 1.49 \\
\hline $\mathbf{M}_{0} \mathbf{N}_{120} \mathbf{P}_{30}$ & 1.30 & 1.33 & 1.35 & 1.33 \\
\hline$M_{6} N_{80} P_{0}$ & 1.37 & 1.37 & 1.43 & 1.39 \\
\hline Mean & 1.35 & 1.37 & 1.41 & - \\
\hline \multirow{2}{*}{\multicolumn{5}{|c|}{$\begin{array}{l}\mathrm{R}=0.07, \quad \mathrm{~W}=0.05, \quad \mathrm{RxW}=\mathrm{NS} \\
\mathbf{M n}\left(\mathbf{m g ~ k g}^{-1}\right)\end{array}$}} \\
\hline & & & & \\
\hline $\mathbf{M}_{0} \mathbf{N}_{120} \mathbf{P}_{0}$ & 93.20 & 92.45 & 86.22 & 90.62 \\
\hline $\mathbf{M}_{6} \mathbf{N}_{80} \mathbf{P}_{30}$ & 84.27 & 81.24 & 73.55 & 79.69 \\
\hline $\mathbf{M}_{0} \mathbf{N}_{120} \mathbf{P}_{30}$ & 95.28 & 87.09 & 84.63 & 89.00 \\
\hline$M_{6} \mathbf{N}_{80} P_{0}$ & 84.11 & 77.37 & 71.05 & 77.51 \\
\hline Mean & 89.22 & 84.54 & 78.86 & - \\
\hline $\operatorname{LSD}(p<0.05)$ & \multicolumn{4}{|c|}{$\mathrm{R}=2.07, \quad \mathrm{~W}=2.80, \quad \mathrm{RxW}=\mathrm{NS}$} \\
\hline \multicolumn{5}{|c|}{ Total-Mn (mg kg $\left.{ }^{-1}\right)$} \\
\hline $\mathbf{M}_{0} \mathbf{N}_{120} \mathbf{P}_{0}$ & 192.1 & 190.1 & 187.1 & 189.8 \\
\hline $\mathbf{M}_{6} \mathbf{N}_{80} \mathbf{P}_{30}$ & 196.9 & 195.5 & 193.2 & 195.2 \\
\hline $\mathbf{M}_{0} \mathbf{N}_{120} \mathbf{P}_{30}$ & 188.1 & 186.8 & 185.0 & 186.7 \\
\hline$M_{6} N_{80} P_{0}$ & 201.5 & 198.9 & 197.0 & 199.2 \\
\hline Mean & 194.7 & 192.9 & 190.6 & - \\
\hline $\operatorname{LSD}(p<0.05)$ & \multicolumn{4}{|c|}{$\mathrm{R}=0.30, \quad \mathrm{~W}=0.48, \quad \mathrm{RxW}=\mathrm{NS}$} \\
\hline
\end{tabular}

The significant higher concentration that ranged from 20.20 to $20.70 \mathrm{mg} \mathrm{kg}^{-1}$ of this fraction was noticed in the treatments where organic manure @ $6 \mathrm{t} \mathrm{ha}^{-1}$ was incorporated along with $\mathrm{N} @ 80 \mathrm{~kg} \mathrm{ha}^{-1}$ and $\mathrm{P}_{2} \mathrm{O}_{5} @ 30 \mathrm{~kg}$ $\mathrm{ha}^{-1}$ were applied. Similar increase was observed in the treatments where organic manure@6 t ha ${ }^{-1}$ was incorporated along with $\mathrm{N} @ 80 \mathrm{~kg} \mathrm{ha}^{-1}$ was applied without incorporation of phosphatic fertilizer where it ranged from 20.50 to $21.67 \mathrm{mg} \mathrm{kg}^{-1}$. The higher concentrations of CFeOX-Mn reported that $\mathrm{Mn}$ requirement can be maintained from this fraction as $\mathrm{Mn}$ associated with $\mathrm{CFeOX}$ released more concentration of $\mathrm{Mn}$ in the soil solution. Singh et al., (1988) in a study on 11 soils reported that 11 and 17 per cent of total $\mathrm{Mn}$ were associated with $\mathrm{CFeOX}$ fraction. 
The significant increase was noticed in organically bound fraction (OM-Mn) in the treatments where organic manure was incorporated along with chemical fertilizers were applied where it ranged from 1.44 to $1.55 \mathrm{mg} \mathrm{kg}^{-1}$ and 1.37 and $1.43 \mathrm{mg} \mathrm{kg}^{-1}$ as compared to the treatment which were treated inorganically and it ranged from 1.26 to 1.30 $\mathrm{mg} \mathrm{kg}$ and 1.30 to $1.35 \mathrm{mg} \mathrm{kg}^{-1}$, also no organic manure was incorporated in these treatments. However, the significant difference was also observed in OM-Mn fraction in case of wheat crop where different levels of $\mathrm{P}_{2} \mathrm{O}_{5}\left(0,30\right.$ and $\left.60 \mathrm{~kg} \mathrm{ha}^{-1}\right)$ were applied. The interaction between rice and wheat crops was found as non-significant. The higher concentration of OM-Mn in the soil solution indicated that the micronutrients associated with the OM bound fraction may play a beneficial role in the uptake of these nutrients by the plants.

Sekhon et al., (2006) reported that OM bound fraction of Mn increased with application of organic manure in rice-wheat system.

The RES-Mn varied from 71.05 to $93.20 \mathrm{mg}$ $\mathrm{kg}^{-1}$ in all the treatments. The concentration for RES-Mn was observed higher as compared to all other fractions except total $\mathrm{Mn}$ fraction. The higher level of $\mathrm{Mn}$ in these fractions under rice-wheat cropping system may be due to effect of submergence.

In conclusion, the inter conversion of $\mathrm{Fe}$ and $\mathrm{Mn}$ from one fraction to the other was accelerated with the addition of the manure. So, the concentration of $\mathrm{Fe}$ and $\mathrm{Mn}$ were found higher in the treatments where biogas slurry was incorporated along with inorganic fertilizers in different fractions viz. WSEX, SpAd, MnOX, AFeOX, CFeOX, OM-bound, RES and Total. The residual (RES) fraction is the dominating fraction among all the different fractions. Water soluble and exchangeable (WSEX) fraction contributes little as compared to the other fractions viz. Crystalline Fe-oxide ( $\mathrm{CFeOX})$ and Amorphous Fe-oxide (AFeOX) fractions. The organic compounds released during decomposition of manures enhanced the availability of $\mathrm{Fe}$ and $\mathrm{Mn}$ by preventing fixation, oxidation, precipitation and leaching.

\section{References}

Agbenin, J. O. 2003. The distribution and transformation of iron and manganese in soil fraction in a savanna alfisol under continuous cultivation. Nutr $\mathrm{Cycl}$ Agroecos 66:259-270.

Behera, S. K., Singh, D. and Dwivedi, B. S. 2009. Changes in fractions of iron, manganese, copper and zinc in soil under continuous cropping for more than three decades. Commun Soil Sci Pl Anal 40:1380-1407.

Chao, T. T. 1972. Selective dissolution of manganese oxide form soil and sediments with acidified hydroxyl chloride. Soil Sci Soc Am J 36:164-68.

Chatterjee, J., Mandal, B., Hazara, G. C. and Mandal, L. N. 1992. Transformation of native and applied zinc in laterite soils under submergence. J Indian Soc Soil Sci. 40: 66-70.

Dhaliwal, S. S. 2008. Different chemical pools of manganese as influenced by submergence, green manure and soil applied manganese under rice - wheat system. An Asian J Soil Sci3:94-98.

Duhan, B. S. and Singh, M. 2002. Effect of green manuring and nitrogen on yield and uptake of micronutrients by rice. $J$ Indian Soc Soil Sci 50:73-81.

Hellal, F. A. 2007.Composite of rice straw and its influences on Iron availability in calcareous soil. Res J Agric \& Biol Sci 3:105-114.

Herencia, J. F., Ruiz, J. C., Melero, M. S., Villaverde, J. and Maqueda, C. 2008. Effect of organic and mineral 
fertilization on micronutrient availability in soil. Soil Sci173:69-80.

Iu, K. L., Pulford, I. D. and Duncan, H. L. 1981. Influence of water logging and lime or organic matter addition on the distribution of trace metals in an acid soil. Pl Soil 59:317-326.

Iwaski, K., Yoshikawa, G. and Sakurai, K. 1993. Fractionation of zinc in greenhouse soils. Soil Sci $\mathrm{Pl} \mathrm{Nutr}$ 39:507-515.

Li, B. Y., Huang, S. M. and Wei, M. B.2010. Dynamics of soil and grain micronutrients as affected by long-term fertilization in an aquicinceptisol. Pedosphere 20:725-735.

Li, B. Y., Zhou, D. M. and Cang, L.2007.Soil micronutrient availability to crops as affected by long-term inorganic and organic fertilizer applications. Soil Till Res 96:166-173.

Manchanda, J. S., Nayyar, V. K. and Chhibba, I. M. 2006 Speciation of exchangeable and crystalline of oxide bound $\mathrm{Zn}, \mathrm{Cu}$, $\mathrm{Fe}$ and $\mathrm{Mn}$ ions form calcareous soils during sequential fractionation. Chem Spec Bioavail., 18:27-37.

Mann, K., Brar, B. and Dhillon, N. 2006. Influence of long-term use of farmyard manure and inorganic fertilizers on nutrient availability in a Typic Ustochrept. Indian J AgricSci 76:477480.

Maskina, M. S., Singh, B., Singh, Y., Baddesha, H. S. and Meelu, O. P. 1998. Fertilizers requirement of rice-wheat and maize-wheat rotations on coarsetextured soils amended with farmyard manure. Fertil Res 17:153-164.

Meena, B. L., Singh, A. K., Phogat, B. S. and Sharma, H. B. 2013. Effects of nutrient management and planting systems on root phenology and grain yield of wheat. Indian J Agril Sci 83: 627-632.

Nayyar, V. K. And Chhibba, I. M. 2000. Effect of green manuring on micronutrient availability in rice-wheat cropping system in northwest India in: Long term soil fertility experiments in rice wheat cropping system. Abrol, I. P., Bronson, K. F., Duxbury, J. M. and Gupta, R. K. (Eds) Rice-wheat consortium paper series 6. Rice-wheat consortium for Indo-Gangetic Plains, New Delhi. India. pp 68-72.

Panse, V. G. and Sukhatme, P. V. 1985.Statistical methods for agricultural workers $4^{\text {th }}$ Edn. ICAR, New Delhi, pp 359.

Raja, M. E. and Iyengar, B. R. V. 1986. Chemical pools of zinc in some soils as influenced by sources of applied zinc. $J$ Indian Soc Soil Sci 34:97-105.

Randhawa, H. S. and Singh, S. P. 1997.Distribution of manganese fractions in alluvium-derived soils in different agro-climatic zones of Punjab. J Indian Soc Soil Sci 45:53-57.

Rehman, H., Aziz, T. and Farooq, M. 2012. Zinc nutrition in rice production systems: A review. Pl Soil 361:203226.

Sekhon, K. S., Singh, J. P. and Mehla, D. S. 2006. Long-term effect of varying nutrient management practices on the distribution of native iron and manganese in various chemical pools under a rice-wheat cropping system. Arch Agron Soil Sci., 53:253-261.

Singh, A. K., Meena, M. K. and Bharati, R. C. 2011.Sulphur and zinc nutrient management in rice lentil cropping system. International Conference on "Life Science Research for Rural and Agricultural Development" 27-29 December, 2011, CPRS Patna (Bihar) 66-7.

Singh, A. K. and Kumar, P. 2009. Nutrient management in rainfed dryland agro ecosystem in the impending climate change scenario. Agril Situ India 65:265-270. 
Singh, J. P., Karwasra, S. P. S. and Singh, M. 1988. Distribution and forms of copper, iron, manganese and zinc in calcareous soils of India. J Indian Soc Soil Sci., 146:359-366.

Walia, M. K., Walia, S. S. and Dhaliwal, S. S. 2010. Long-term effect of integrated nutrient management of properties of Typic Ustochrept after 23 cycles of irrigated rice (Oryza sativa L.)-wheat (Triticum aestivum L.) system. J Sustain Agric 34: 724-743.

Xue, Y., Yue, S. and Zhang, W.2014. Zinc, iron, manganese and copper uptake requirement in response to nitrogen supply andthe increased grain yield of summer maize. PLoS One, 9:e93895.

\section{How to cite this article:}

Dhaliwal, M.K., S.S. Dhaliwal and Shukla, A.K. 2019. Long Term Effect of Manure and Fertilizers on Chemical Fractions of Fe and Mn in Surface Soils under Rice-Wheat System. Int.J.Curr.Microbiol.App.Sci. 8(02): 3165-3178. doi: https://doi.org/10.20546/ijcmas.2019.802.370 